\title{
GEOCHEMISTRY AND MAGMATIC EVOLUTION OF EXPLOSIVE TEPHRAS ET3 AND ET4 FROM ARENAL VOLCANO, COSTA RICA
}

\author{
Louise L. Bolge ${ }^{1 *}$, Michael J. Carr ${ }^{1}$, Mark D. Feigenson ${ }^{1} \&$ Andrea Borgia ${ }^{2}$ \\ ${ }^{1}$ Department of Geological Sciences, Rutgers University, Piscataway NJ, USA \\ ${ }^{2}$ EDRA, Via di Fioranello 31, 00134 Roma \\ * Author for contact: lbolge@ @rci.rutgers.edu
}

(Recibido 10/03/03; aceptado 22/06/03)

\begin{abstract}
An outcrop at El Cruce, $5.7 \mathrm{~km}$ from the vent of Arenal volcano, exposes thick sequences of two recent tephras, ET4 (silicic) and, immediately above, ET3 (mafic). The ET4 to ET3 transition is abrupt, with no soil between the layers. Therefore, they appear to be part of one eruptive phase. A petrological model is inferred from the detailed stratigraphic record of these eruptions. The ET4 sequence can be modeled by crystal fractionation via gravity settling. ET4 is most mafic at the top of the section. The silicic tephra at the bottom of this unit is aphyric. Compatible elements increase and incompatible elements decrease moving down through the magma chamber. The percentage of phenocrysts increases through the top. Models of crystal fractionation, using the most mafic and phenocryst enriched tephra as the parent magma, produce the most silicic tephra by removal of 37\% phenocrysts. The ET3 sequence shows the opposite trend of that seen in the ET4 sequence, becoming less enriched in incompatible elements down through the section. Some crystal sorting, followed by the removal of a silicic melt from the top of the magma chamber, could generate the reversed trend for the ET3 sequence.
\end{abstract}

Keywords: Arenal volcano, magmatic evolution, silicic tephras, mafic tephras, stratigraphy, crystal fractionation, parent magma.

RESUMEN: Un afloramiento en El Cruce, a 5,7 km del cráter del volcán Arenal, expone una espesa secuencia con dos tefras recientes: ET4 (silícea) e inmediatamente arriba ET3 (máfica). La transición de ET4 a ET3 es abrupta, sin suelo entre ellas. En consecuencia, parecen ser parte de una sola fase eruptiva. Se infiere un modelo petrológico a partir del registro estratigráfico de estas erupciones. La secuencia de ET4 se puede modelar por cristalización fraccionada por depositación gravitacional, en donde el techo de la sección es más máfico. La tefra silícea en la base de ET4 es afírica. Los elementos compatibles se incrementan y los incompatibles disminuyen conforme se avanza hacia el piso de la cámara magmática. La cantidad de fenocristales se incrementa hacia el techo. Los modelos de cristalización fraccionada usando las tefras más máficas y ricas en fenocristales como el magma parental, producen las tefras más silíceas por remoción del 37\% de los fenocristales. La secuencia de ET3 muestra el patrón opuesto al visto en ET4, tornándose menos enriquecida en elementos incompatibles conforme bajamos en la sección. Alguna selección de cristales, seguida de la remoción del fundido silíceo del techo de la cámara magmática, podría generar el patrón inverso para la secuencia de ET3.

Palabras clave: volcán Arenal, evolución magmática, tefras silíceas, tefras máficas, estratigrafía, cristalización 


\section{INTRODUCTION}

Arenal is a small stratovolcano located in northwestern Costa Rica ( $10^{\circ} 27.8^{\prime} \mathrm{N}, 8^{\circ}{ }^{\circ} 42.3^{\prime}$ W) near the southern end of the Central American Volcanic Arc (Malavassi, 1979). It is the youngest and most active volcano in Costa Rica (Melson, 1994). Arenal's volcanics consist of both lava and tephra (e.g. Borgia et al., 1988; Reagan et al., 1987).

On July 29, 1968, Arenal Volcano erupted with a violent directed blast (Melson \& Sáenz, 1973). Prior to this 1968 eruption, Arenal was thought to be extinct. The initial blast was followed by a pyroclastic explosion. The explosive tephra of 1968, referred to as ET1, consists of a basal coarse lapilli layer overlain by fine tephras, deposited on a thick soil horizon formed since the last large eruption (Melson, 1994). Compared to the other tephra layers, ET1 is very thin. In most of the region covered by Arenal's tephra sequence, ET1 is no longer visible. After the initial tephra eruption, a nearly continuous series of lava flows erupted from 1968 to the present. Several small pyroclastic flows have occurred, most recently in 2001 (Alvarado \& Soto, 2002)

A prehistoric tephra sequence underlies the 1968 tephra. The type section, El Tajo, is approximately $7 \mathrm{~km}$ due west and downwind of Arenal's summit. The El Tajo exposure now lies beneath Laguna Arenal. It was $21 \mathrm{~m}$ thick and $200 \mathrm{~m}$ wide. Nine distinct tephra units were found in El Tajo, and most were covered by a soil or paleosol layer, indicating a substantial repose between eruptions (Melson, 1982, 1984, 1994). Further fieldwork by Soto et al. (1998) has shown at least 22 distinctive tephra units, covering a 7000 year time span. In general, the tephra units alternate in composition from dacitic to basaltic andesite.

\section{Purpose of this study}

This study focuses on the silicic and the mafic tephras of the most recent dacite - basalt sequence, ET4 and ET3. Tephras were collected from a road intersection, called El Cruce (CT samples), approximately $5.7 \mathrm{~km}$ west of Arenal. These tephras are relatively thick sections consisting of multiple layers of lapilli. Their thickness, layering and preservation make these tephras ideal to analyze.

The purpose of this study is to define the magmatic processes that govern the geochemical evolution of these two well exposed tephras at Arenal. The initial objective is to obtain a high quality data set against which models of magmatic evolution can be evaluated. The second goal is to make a comprehensive petrological model for these two tephras that can help constrain the overall magmatic evolution at Arenal, especially its repeated pattern of alternation of silicic and mafic tephras.

\section{Analytical methods}

Geochemical data for these two tephra sequences were collected using four different analytical methods. Bulk analysis on major element oxides and some trace elements have been performed on a DCP-AES, whole rock trace element analyses, including REE, on a Finningan MAT HR-ICP-MS at Rutgers University (data available online at www.geologia.ucr.ac.cr). Microprobe analyses of the minerals and glass in the ET3 sequence have been made for major element oxides and a few trace elements at the Smithsonian's National Museum of Natural History (available online at www.geologia.ucr.ac.cr). $\mathrm{Sr}, \mathrm{Nd}$ and $\mathrm{Pb}$ isotopes for selected samples have been analyzed on a VG Sector TIMS at Rutgers University.

\section{RESULTS}

We use a plot of $\mathrm{Cs} / \mathrm{Rb}$ versus $\mathrm{K} / \mathrm{Ba}$ (Fig. 1) to identify samples whose trace element concentrations appear to have been modified by post magmatic processes. We utilize these elements because of their large ionic ratios and fluid mobility. T0en samples out of 41 have been excluded from the modeling based on Fig. 1. Samples CT3F, CT3G, CT3AA, CT3AB, CT3AC, and CT3AD are removed because of their dispersion away from the majority of the samples. They all have either considerably higher $\mathrm{Cs} / \mathrm{Rb}$ ratios and/or lower $\mathrm{K} / \mathrm{Ba}$ ratios than 


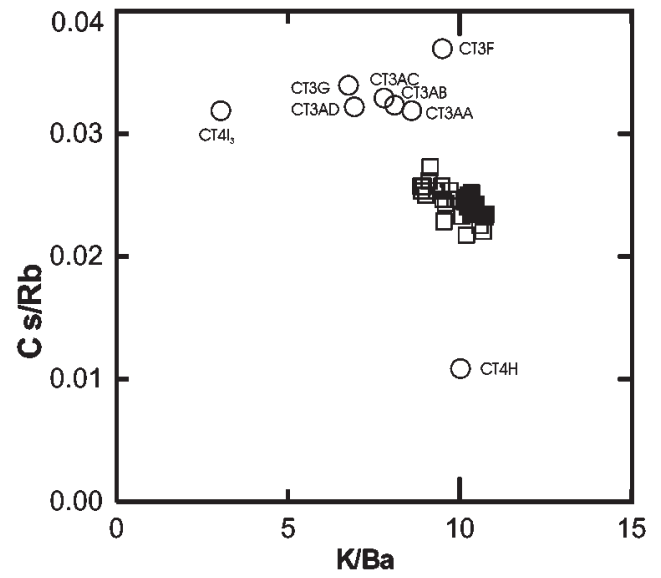

Fig. 1: Ratio $\mathrm{Cs} / \mathrm{Rb}$ versus $\mathrm{K} / \mathrm{Ba}$ for the sequence $\mathrm{ET} 3$ and ET4. The ET4 samples are the filled squares, the ET-3 are open squares and the flagged samples are open circles.

the other tephras. It is not surprising that some of the tephras show the effects of weathering. The lapilli in these layers range from a few millimeters up to a few centimeters in size. The small size, high porosity and high glass content make them susceptible to weathering, especially given the high rainfall in the area.

Sample $\mathrm{CT}_{4} \mathrm{I}_{3}$ is flagged due to its unique and extremely high $\mathrm{Ba}$ concentration, which is likely the result of some type of contamination, and not analytical error. The high Ba concentration is seen in both the DCP-AES and HR-ICPMS which undergo two separate sample preparations. Sample CT4H, a member of the dacitic tephra sequence, has elemental concentrations similar to the ET3 tephras. CT4H also has a con- siderably lower $\mathrm{Cs} / \mathrm{Rb}$ ratio relative to all the other tephras. Sample CT3I and CT3H are flagged due to their mafic nature. These two samples are interpreted as fragments of wall rock blown out with the ET3 tephras. All of these flagged tephra samples are included in the figures, but plotted as small circles. Although these tephras are likely to have been weathered or contaminated, these processes only affect a few elements (primarily $\mathrm{Ba}, \mathrm{Cs}, \mathrm{Rb}, \mathrm{K}$ ).

To assess the effects of weathering, we made thin sections of the lapilli remaining in the collection. Sample CT3G shows significant evidence of alteration as the outer rims of the lapilli are completely oxidized. CT3G consists of mostly altered plagioclase and glass with little to no pyroxene. Sample CT4H displays a different texture than the ET3 or ET4 tephras, indicating a separate origin for this tephra. CT4H appears holocrystalline with no vesicles and with equigranular crystals approximately $0.5 \mathrm{~mm}$ in diameter. ET3 samples are extremely vesicular with a glassy matrix and phenocrysts ranging from approximately 0.05 to 1 $\mathrm{mm}$ in diameter. ET4 samples consist of microlites in a glass matrix with phenocrysts similar in size to ET3 but much less abundant. Weathering is not surprising because the samples are porous and glassy. CT4H appears holocrystalline with no vesicles and with equigranular crystals approximately $0.5 \mathrm{~mm}$ in diameter.

New isotopic data, listed in Table 1, show no significant crustal contamination. The Arenal ${ }^{87} \mathrm{Sr} /{ }^{86} \mathrm{Sr}$ and ${ }^{143} \mathrm{Nd} /{ }^{144} \mathrm{Nd}$ data plot along the positively correlated trend shown by Carr et al.

Table 1: Isotopic data

\begin{tabular}{|c|c|c|c|c|c|c|}
\hline Sample & ${ }^{87} \mathrm{Sr} /{ }^{86} \mathrm{Sr}$ & \pm & ${ }^{143} \mathrm{Nd} /{ }^{144} \mathrm{Nd}$ & \pm & & \\
\hline CT 3B & 0.703824 & 5 & 0.513009 & 9 & & \\
\hline CT $3 \mathrm{~F}$ & 0.703839 & 6 & 0.513009 & 5 & & \\
\hline CT 3L & 0.703808 & 6 & 0.512997 & 10 & & \\
\hline CT 3P & 0.703829 & 14 & 0.512920 & 7 & & \\
\hline CT $3 Z$ & 0.703806 & 10 & & & & \\
\hline CT $3 \mathrm{AG}$ & 0.703828 & 5 & 0.513034 & 72 & & \\
\hline CT 4A & 0.703798 & 5 & 0.513004 & 16 & & \\
\hline CT 4G & 0.703807 & 15 & 0.513004 & 16 & & \\
\hline CT 4L & 0.703853 & 11 & 0.513013 & 25 & & \\
\hline Sample & ${ }^{206} \mathrm{~Pb} /{ }^{204} \mathrm{~Pb}$ & \pm & ${ }^{207} \mathrm{~Pb} /{ }^{204} \mathrm{~Pb}$ & \pm & ${ }^{208} \mathrm{~Pb} /{ }^{204} \mathrm{~Pb}$ & \pm \\
\hline CT 3L & 18.892 & 0.009 & 15.591 & 0.012 & 38.540 & 0.035 \\
\hline CT 4A & 18.975 & 0.002 & 15.665 & 0.002 & 38.965 & 0.006 \\
\hline
\end{tabular}


(1990) for Central America. The Arenal data plot in the same region as other Costa Rican arc magmas (Fig. 2a and 2b).

\section{DISCUSSION}

In order to visualize processes occurring in the magma chamber, we plot element
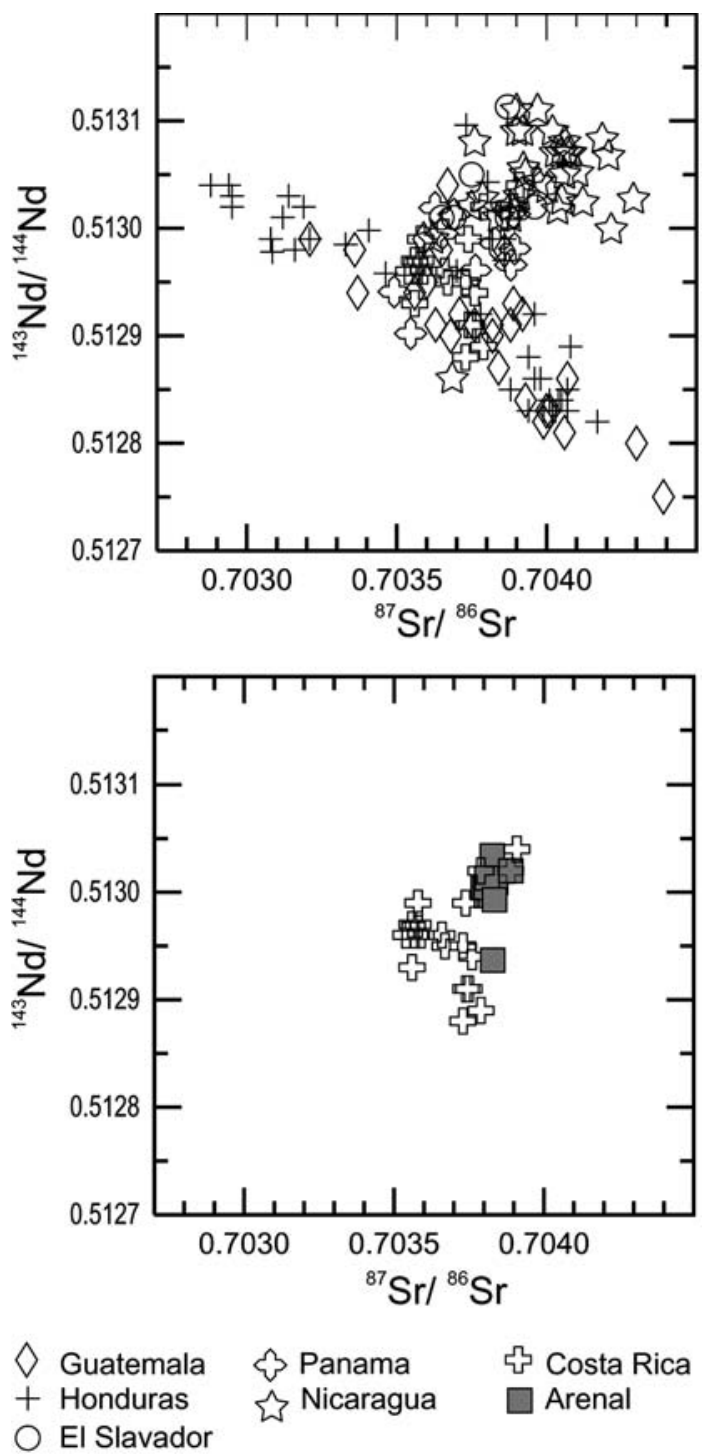

Fig. 2: Isotopic ratios ${ }^{143} \mathrm{Nd} /{ }^{144} \mathrm{Nd}$ versus ${ }^{87} \mathrm{Sr} /{ }^{86} \mathrm{Sr}$ for a) Central American rocks (data from Carr et al., 1990) and b) Costa Rica and Arenal volcano rocks. concentrations against inverted stratigraphy. By inverting the stratigraphy, each sample is assumed to be in its relative position in the preeruptive magma chamber. This simple model assumes an uncomplicated drawdown in these two relatively small eruptions. The samples that plot at the top of the figures erupted first, and therefore resided near the top of the magma chamber. The samples at the bottom of the figures erupted last, and presumably resided nearer the bottom of the magma chamber. ET4 is above ET3 in the magma chamber because it erupted first.

\section{ET4 sequence}

The ET4 sequence shows the effects of crystal settling and compaction. Incompatible elements increase upwards in the magma chamber as phenocryst content decreases. Because of this, the ET4 model is crystallization and incomplete crystal removal. There are increases in $\mathrm{Al}_{2} \mathrm{O}_{3}, \mathrm{FeO}, \mathrm{MgO}$, and $\mathrm{CaO}$ (Fig. 3) downward through the magma chamber, resulting from crystal settling. Accumulation of ferromagnesian minerals (i.e., pyroxene, hornblende and magnetite) accounts for the increase in $\mathrm{FeO}$ and $\mathrm{MgO}$. The increase in $\mathrm{CaO}$ is the result of clinopyroxene and plagioclase accumulation. This downward increase is also displayed by $\mathrm{Sr}$, which can be explained by plagioclase accumulation. Scandium, $\mathrm{TiO}_{2}$, and $\mathrm{V}$ increase downwards through the magma chamber, the result of pyroxene ( $\mathrm{Sc}$ ) and magnetite accumulation $\left(\mathrm{TiO}_{2}, \mathrm{~V}\right)$.

$\mathrm{SiO}_{2}, \mathrm{~K}_{2} \mathrm{O}$ (Fig. 3), $\mathrm{Na}_{2} \mathrm{O}$, and $\mathrm{P}_{2} \mathrm{O}_{5}$ increase upwards through the magma chamber. Incompatible element rich liquids are more abundant higher in the magma chamber, because the crystals formed by the compatible major element oxides are redistributed to lower levels in the magma chamber. The incompatible elements ( $\mathrm{Ba}, \mathrm{Rb}, \mathrm{Cs}, \mathrm{Y}, \mathrm{Zr}$, Th, U, and REE's; Fig. 3) also increase towards the top of the magma chamber.

A petrologic mixing program (Bryan et al., 1969) confirms this crystal fractionation model, using average phenocryst mineral compositions (calculated from microprobe data on the CT3 

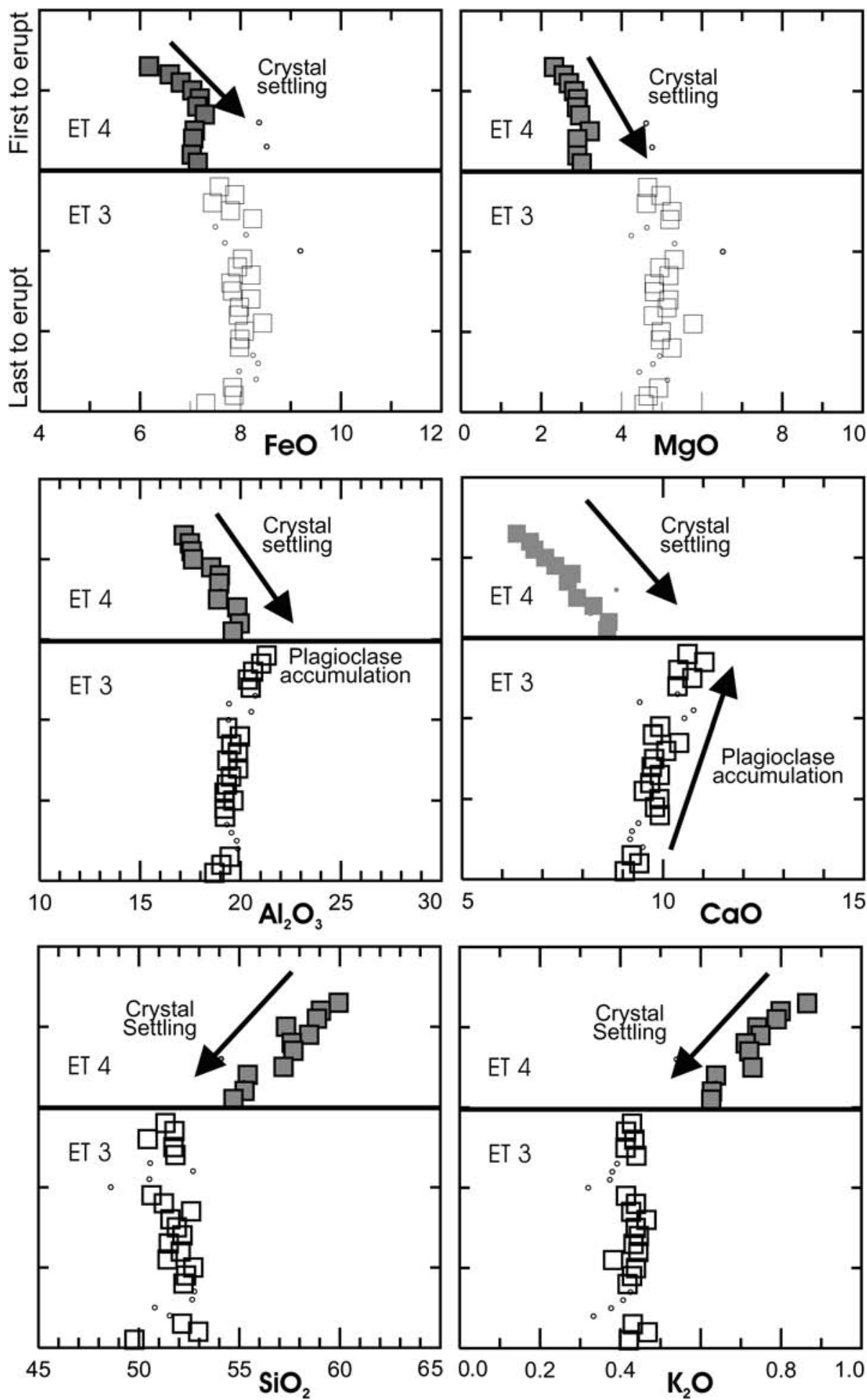

Fig. 3: Inverted stratigraphic order (as in the magmatic chamber) of ET3 and 4 versus major oxides, and normalized values of incompatible trace elements trends, illustrating the processes of crystal settling and plagioclase accumulation. 

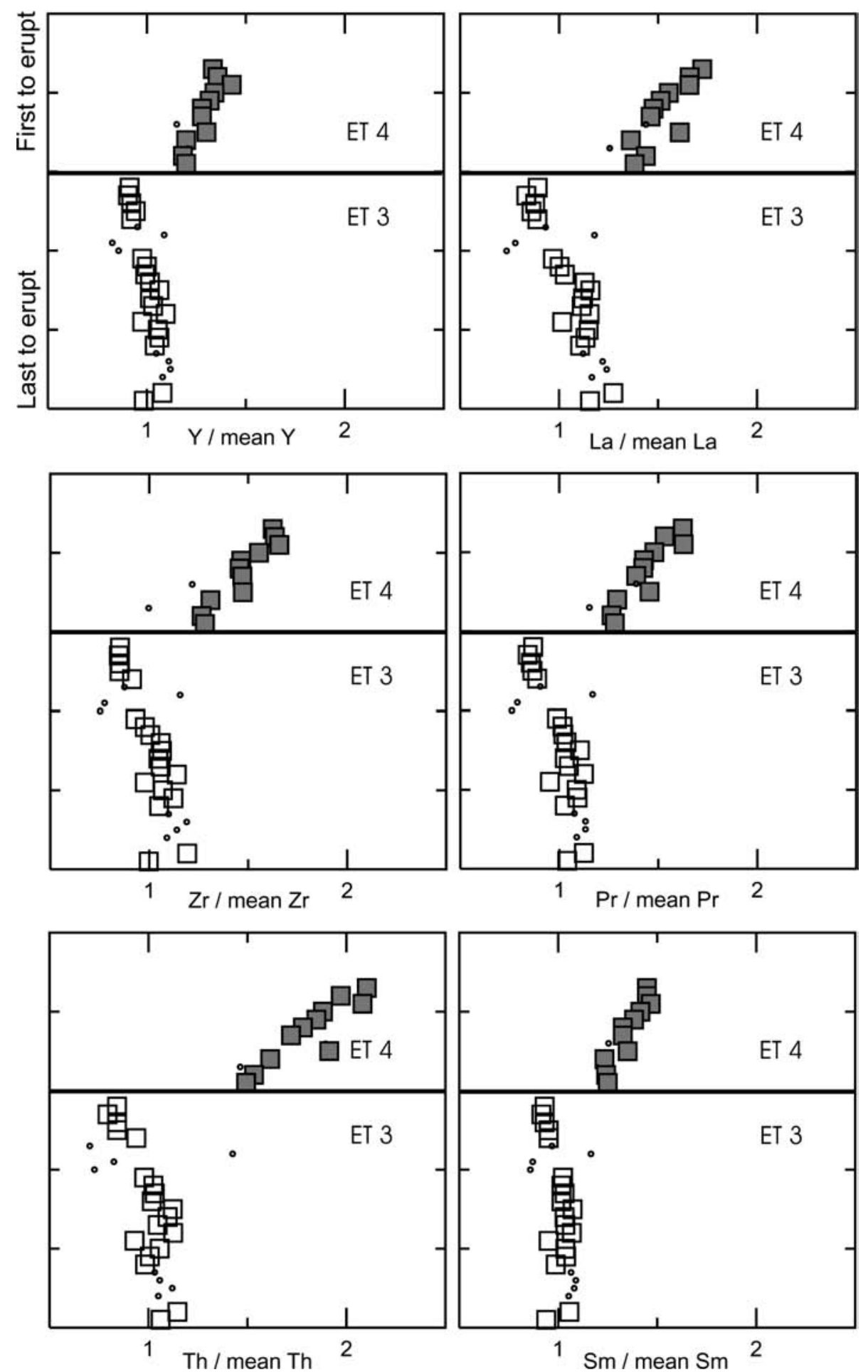

Fig. 3 (cont.): Inverted stratigraphic order (as in the magmatic chamber) of ET3 and 4 versus major oxides, and normalized values of incompatible trace elements trends, illustrating the processes of crystal settling and plagioclase accumulation. 
samples), CT4L as the parent magma and CT4A as the daughter. Tephra sample CT4L consists of $63 \%$ CT4A liquid and $37 \%$ crystals of plagioclase, hornblende, magnetite, and pyroxene. The percentages of the different minerals, calculated by least squares, are very similar to the modal analysis of phenocrysts in tephra CT4L (Table 2).

Carr \& Walker (1987) examined ET4 samples from the El Tajo section. They noted that the first erupted tephra (that highest in the magma chamber) was virtually aphyric, followed by progressively more phenocrysts during the eruption. El Tajo sample 4A was the first to erupt and was therefore located at or near the top of the magma chamber. It is the equivalent of CT4A. El Tajo sample $4 \mathrm{~F}$ was the last to erupt, and is therefore the equivalent of CT4L. The modal percentages of El Tajo sample 4F and CT4L are virtually the same (Table 2).

\section{ET3 sequence}

The origin of the ET3 tephras is not as clear as for the ET4 tephras. To simplify the 40 plus elements analyzed for the ET3 sequence, the tephras have been broken down into three basic components: glass, plagioclase and mafic minerals. A simple mixing program is used to calculate a weight percent for each phase in the tephras using elemental concentrations for the whole rock and for the individual mineral phases or glass. We first calculate average compositions for each phase seen in the tephras: olivine, magnetite, hornblende, clinopyroxene, plagioclase, and glass from the microprobe analyses performed on the CT3 tephra samples. These averages do not include the tephras flagged for various reasons described above. Next we utilize a mixing program in which we treat each mineral phase and glass as separate components. Mineral phases and glass are then mixed in various proportions to reproduce the whole rock analysis for each tephra, using least squares modeling.

The amount of calculated plagioclase increases upwards through the magma chamber while the amount of glass decreases (Fig. 4). Plagioclase and glass are the dominant phases, composing $90 \%$ of the rocks. The remaining $10 \%$ consist of pyroxene, hornblende, olivine and magnetite, whose calculated modal propor-

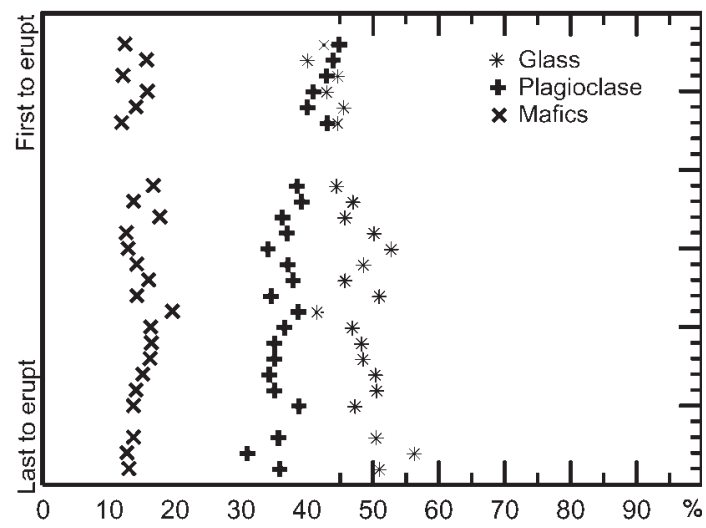

Fig. 4: The calculated percentages of phases in the ET3 tephras.

Table 2

ET4 tephra modal analysis

\begin{tabular}{|c|c|c|c|c|c|c|}
\hline & \multicolumn{3}{|c|}{$\begin{array}{c}\text { Modal analyses } \\
\text { (Carr \& Walker, 1987) }\end{array}$} & \multicolumn{2}{|c|}{$\begin{array}{l}\text { Modal analyses } \\
\text { (this study) }\end{array}$} & \multirow{2}{*}{$\begin{array}{c}\text { Fractional } \\
\text { crystallization } \\
\text { Model }\end{array}$} \\
\hline & $4 \mathrm{~A}$ & $4 \mathrm{~B}$ & $4 \mathrm{~F}$ & CT4L & $\begin{array}{c}\text { CT4L \% } \\
\text { phenocrysts }\end{array}$ & \\
\hline Groundmass & 99 & 95 & 85 & 84 & & \\
\hline Plagioclase & Traces & 2 & 12 & 13 & 76 & 75.2 \\
\hline Hornblende & Traces & Traces & 1 & 2 & 12 & 11.9 \\
\hline Magnetite & Traces & 3 & 2 & 2 & 12 & 7.2 \\
\hline Pyroxene & - & - & Traces & Traces & Traces & 5.7 \\
\hline
\end{tabular}


tions remain roughly constant throughout the ET3 sequence. Moving upwards through the magma chamber, plagioclase becomes enriched relative to the mafics. These calculations agree with the point count trends of thin sections. The point counts give a slightly higher percentage (approximately 5\%) of glass than is found with the least squares modeling.

The microprobe analyses on the glass found in the ET3 sequence show a constant chemical composition throughout this entire sequence, so whole rock variations are due to different proportions of glass, not variations in glass chemistry. Furthermore, the chemical composition of the glass in the ET3 sequence is similar to that of the most aphyric ET4 samples.

Most of the major element oxides are constant throughout the ET3 sequence, (e.g. FeO and $\mathrm{MgO}$, Fig. 3), consistent with the relatively constant abundance of mafic minerals throughout the section. There are no obvious trends, except for $\mathrm{Al}_{2} \mathrm{O}_{3}$ and $\mathrm{CaO}$. There is a cluster of CT3 samples (CT3A through CT3H, but not including $\mathrm{CT} 3 \mathrm{G}$ ) with an elevated amount of $\mathrm{Al}_{2} \mathrm{O}_{3}$. Since this is at the top of the sequence, it could be the result of plagioclase flotation or less effective settling. Plagioclase has a low density compared to the other minerals present, and can become buoyant if gas bubbles nucleate on the plagioclase (Rose et al., 1978). Even if it does not float, plagioclase will sink more slowly than mafic minerals due to its lower density. $\mathrm{CaO}$ increases upward through the ET3 sequence, due to the upward increase in modal plagioclase. In similar fashion, the incompatible elements decrease upwards in ET3, due to the relative decrease in glass upwards through the magma chamber.

To compare incompatible trace element trends on a similar scale, we plot stratigraphic position versus normalized values, in which each element is divided by its mean value in ET3 (Fig. 3). A close examination of the incompatible elements from ET3 shows that the extent of variation is a function of the relative incompatibility. The REE display this trend best: La shows the greatest depletion upwards in the magma chamber, followed by $\mathrm{Ce}, \mathrm{Pr}, \mathrm{Nd}$ and the remaining REEs. The extent of depletion mirrors the elemental incompatibility (e.g. La, which is the most incompatible, is the most depleted; $\mathrm{Ce}$, which is less incompatible that $\mathrm{La}$, is less depleted than $\mathrm{La}$, and so on for $\mathrm{Pr}$ and $\mathrm{Nd}$.)

Removing some of the siliceous melt near the top of the magma chamber removes incompatible elements from the uppermost tephras because the siliceous melt is rich in incompatible elements. By removing some siliceous liquid from the top of the ET3 magma body, the uppermost magma would be depleted in incompatible elements. This apparent increase in plagioclase upwards is partly the result of a removal of siliceous melt. However, some plagioclase flotation did occur in the uppermost tephras, as shown by the increase in $\mathrm{Al}_{2} \mathrm{O}_{3}$.

One issue arising from this melt model is the amount of $\mathrm{CaO}$ and $\mathrm{Al}_{2} \mathrm{O}_{3}$ in the siliceous melt being removed. For $\mathrm{CaO}$ and $\mathrm{Al}_{2} \mathrm{O}_{3}$ to increase up section, the removed melt must be very low in these elements. According to the microprobe data the glass consists of approximately $7 \mathrm{wt} \% \mathrm{CaO}$, while plagioclase contains approximately $15 \mathrm{wt} \% \mathrm{CaO}$. The glass also consists of approximately $17 \mathrm{wt} \% \mathrm{Al}_{2} \mathrm{O}_{3}$, while plagioclase contains approximately $33 \mathrm{wt} \% \mathrm{Al}_{2} \mathrm{O}_{3}$.

The pattern seen in ET3 is seen in all the incompatible elements except $\mathrm{K}$ and $\mathrm{Rb}$. Potassium behaves similarly to $\mathrm{Na}$ and $\mathrm{P}$, which are nearly constant. Sodium and $\mathrm{P}$ are elements that do not necessarily follow other incompatible trends, because they can enter plagioclase and/or hornblende and apatite respectively. Potassium behaves similarly to $\mathrm{Sm}$. These elements share similar partition coefficients for plagioclase (Gill, 1981) supporting plagioclase control of the bulk distribution coefficients in the ET3 tephras. Rubidium is constant as well, commonly replacing $\mathrm{K}$ in minerals, and thereby following the same trend as $\mathrm{K}$.

\section{CONCLUSION}

For ET3 and ET4, two different but related processes occurred in the same magma chamber. The ET4 tephras are the result of crystal settling and liquid accumulation. There is an increase in 
$\mathrm{MgO}, \mathrm{FeO}, \mathrm{CaO}, \mathrm{Al}_{2} \mathrm{O}_{3}, \mathrm{Sr}, \mathrm{Sc}, \mathrm{TiO}_{2}$, and $\mathrm{V}$ downwards in the magma chamber, caused by compaction as liquid rises and hornblende, pyroxene, plagioclase, and magnetite settle. There is a corresponding increase in incompatible elements upwards in the magma chamber, because of the increase in siliceous liquid.

The ET3 tephras result from crystal accumulation and liquid extraction. Accumulation of and mineral sorting enriched the earlier erupted tephras, the uppermost part of the ET3 sequence in the magma chamber, in plagioclase. The primary evidence for this is the elevated amount of $\mathrm{Al}_{2} \mathrm{O}_{3}$ in the uppermost tephras. Incompatible elements decrease in the ET3 sequence upwards in the magma chamber, resulting from a residual siliceous melt being removed from the top of the ET3 sequence. The depletion of incompatible elements increasing with degree of incompatibility provides evidence for crystal liquid fractionation occurring prior to the removal of the siliceous melt. This is especially evident in the REE.

ET4 and ET3 are most likely comagmatic. They have identical isotopic compositions (Table 1). The constant composition of the glass in the ET3 sequence is comparable to the most aphyric ET4 sample. Although there is not substantial paleosol between the two units, there is an unconformity, indicating some small hiatus between the two units.

\section{REFERENCES}

ALVARADO, G.E. \& SOTO, G.J., 2002: Pyroclastic flow generated by crater-wall collapse and outpouring of the lava pool of Arenal Volcano, Costa Rica. - Bull. Volcanol. 63: 557-568.

BRYAN, W.B., FINGER, L.W. \& CHAYES, F., 1969: Estimating proportions in petrographic mixing equations by least squares approximation. - Science, 163: 926-927.

BORGIA, A., POORE, C., CARR, M.J., MELSON, W.G. \& ALVARADO, G.E., 1988: Structural, stratigraphic, and petrologic aspects of the Arenal-Chato volcanic system, Costa Rica: Evolution of a young stratovolcanic complex. - Bull. Volcanol. 50: 86-105.
CARR, M.J. \& WALKER, J., 1987: Intra-eruption changes in the composition of some mafic to intermediate tephras in Central America. - J. Volcanol. Geotherm. Res. 33: $147-159$.

CARR, M.J., FEIGENSON, M.D. \& BENNET, E.A., 1990: Incompatible element and isotopic evidence for tectonic control of source mixing and melt extraction along the Central American arc. - Contrib. Mineral. Petrol. 105: 369-380.

GILL, J., 1981: Orogenic andesites and plate tectonics. - 390 pags. Springer, Berlin.

MALAVASSI, E., 1979: Geology and petrology of Arenal Volcano, Costa Rica. - 111 pags. University of Hawaii [Thesis M.S.].

MELSON, W.G., 1982: Alternancia entre magmas ácidos y básicos en las erupciones explosivas mayores del Volcán Arenal, Costa Rica. - Bol. de Vulcanol. UNA, 13: $65-74$.

MELSON, W.G., 1984: Prehistoric eruptions of Arenal Volcano, Costa Rica. - Vínculos, 10: 34-59.

MELSON, W.G., 1994: The eruption of 1968 and tephra stratigraphy of Arenal Volcano. - In: SHEETS, P. \& McKEE, B. (eds.): Archaeology, volcanism and remote sensing in the Arenal region, Costa Rica. Univ. Texas Press, Austin: 24-47.

MELSON, W.G. \& SÁENZ, R., 1973: Volume, energy and cyclicity of eruptions of Arenal Volcano. - Bull. Volcanol. 37: 416-437.

REAGAN, M., GILL, J., MALAVASSI, E. \& GARCIA, M., 1987: Changes in magma composition at Arenal volcano, Costa Rica, 1968-1985: Real-time monitoring of open-system differentiation. - Bull. Volcanol. 49: 415-434.

ROSE, W.I. JR., ANDERSON, A.T.JR., WOODRUFF, L.G. \& BONIS, S.B., 1978: The October 1974 basaltic tephra from Fuego Volcano: description and history of the magma body. - J. Volcanol. Geotherm. Res. 4: 3-53.

SOTO, G.J., ALVARADO, G.E. \& GHIGLIOTTI, M., 1998: El registro eruptivo del Arenal en el lapso 3000 - 7000 años antes del presente y nuevas deducciones sobre la edad del volcán. - Bol. OSIVAM, 13-14: 19-49. 